\title{
Sexual disorders and right-wing authoritarianism in Indonesian boarding school
}

Khaerina, Shabrina Septya

Department of Psychology, Bina Nusantara University, Indonesia (shabrinask@ymail.com)

Abraham, Juneman

Department of Psychology, Bina Nusantara University, Indonesia (juneman@binus.edu)

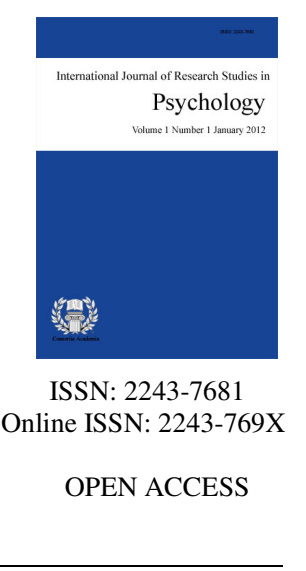

\section{Abstract}

Sexual disorders in Indonesia Islamic boarding schools have been extensively studied. However, there have been no researches that correlate them with right-wing authoritarianism. In this study, right-wing authoritarianism was hypothesized to correlate with the four dimensions of sexual disorders of Garos Sexual Behavior Inventory. This study used correlational design with Spearman's correlation data analysis. There were 271 study participants (140 males, 131 females; $M_{\mathrm{age}}=15.93$ years old; $S D_{\text {age }}=1.69$ years) taken using purposive sampling technique. The research results showed negative correlations between right-wing authoritarianism and sexual stimulation, sexual obsession as well as sexual permissiveness. However, there is no correlation between authoritarianism and sexual discordance. This study does not recommend increasing the level of right-wing authoritarianism based on reasons presented in the Discussion and Conclusion sections.

Keywords: authoritarianism; sexual psychology; Islamic boarding school; Indonesia 


\section{Sexual disorders and right-wing authoritarianism in Indonesian boarding school}

\section{Introduction}

Studies regarding sexuality and sexual behaviors of santri (student) in Indonesia Islamic boarding school have been conducted several times. Paradoxically, in the midst of the religious community living with "sexual taboos", a form of sexual behaviors that is specific and popular among santri is same-sex sexual behavior (both between male santri and another male santri as well as female santri and another female santri), what is known as mairil, dumok, alaq-dalaq, nyempet, muyak lating, lesehan, lesbiola, and others, depending on the locality (Ibrahim, 2013; O’Hanlon, 2006; Rohmah, 2011). According to Saifullah's (2008) systematic observation, sexual behavior in the boarding school is influenced by crowded living quarter of santri thus allowing intensive physical interaction, curiosity and sexual comparison with other people during puberty, limited access with the outside world, absence of Islamic boarding school entry examination thus enabling the entry of santri with sexual orientation disorder as well as recitation containing sexual material conducted in the middle of the night.

A number of previous empirical studies seemed trying to complement Saifullah's study by connecting sexuality and sexual behavior of santri with psychological variables, such as moral reasoning, sexual self-concept, sexual drive, the role of peers, religious dimension, relation with parent, interpersonal communication pattern, sexual knowledge, sexual fantasy, and length of stay in Islamic boarding school (Asfriyati \& Sanusi, 2006; Faizah, 2012; Ibrahim, 2013; Nugrahawati \& Qodariah, 2011; Rahardjo, 2003; Rahardjo, 2010; Sari, 2011; Setiyowati, 2008; Ulya, 2010). Results from those studies varies; where the most of the variables designed by the researchers as the predictors - i.e. moral reasoning, relation with the parent, sexual knowledge, sexual fantasy, and length of stay in Islamic boarding school - were found to not be associated with sexual behavior of santri.

This study focused on santri because the stream has the potential of a significant political power in Indonesia, and it represents the religious power and is highly expected to play a role in terms of moral leadership (Muhammad, 2008). Meanwhile, morality and sexuality possess a strong association (Price, 2013), even more in Indonesia, in which the attitudes of the people toward sexuality tend to be conservative. Sexuality in a number of countries has also become the public domain (Botcherby \& Creegan, 2009), including in Indonesia. Therefore, it is important to investigate the dynamics of sexual disorders among santris at Islamic boarding schools (pesantren) as well as the underlying psychological forces driving their behavior.

This study fills the gap in literature regarding premarital sexual behavior of santri in Islamic boarding school in Indonesia in two ways. First, this study focused on sexual behaviors by following sexual disorders categorization by Sheila Garos (Garos, 1997; Garos \& Stock, 1998; Garos, 2009), i.e. (1) sexual discordance; (2) sexual obsession; (3) sexual permissiveness; and (4) sexual stimulation. In this study, they are referred to as sexual "disorder" because it does not conform to the Eastern culture that is strongly rooted in Indonesia which emphasizes sexual control. Indeed, upon closer look, the first category, namely sexual discordance, is aligned with sexual control. However, in terms of the resulting consequences, this sexual discordance makes people personally susceptible to personal disturbance. This study assumed that same-sex sexual behavior in Indonesia Islamic boarding school described above is simply a "tip of the iceberg", which requires exploring more fundamental factors. Those fundamental factors, in this study, were operationalized as four dimensions of sexual disorders by Garos.

Second, this study is the first which employed right-wing authoritarianism (RWA) as the variable hypothesized to correlate with the four dimensions of sexual disorders. The non-significant correlation between variables designed in previous studies might be because the correlation is indirect. This study assumes that RWA is one of the variables that are very closely related with sexual disorders. 
RWA is a concept that was originally initiated by Adorno, Frenkel-Brunswik, Levinson, and Sanford (1950) as well as Altemeyer (1981) as a concept of "authoritarian personality". This personality originated from chronic motive for power and super-patriotism, which originally developed from parenting pattern that teach children to "burn all immoral impulses" (overdeveloped superego), which later grow into sadistic tendency (dominating other people), or masochistic tendency (dominated by authority in power), to preserve and protect morality, order, power, definiteness, and discipline or strictness in this world (Moskowitz, 2005). Moskowitz also showed through his literature review that authoritarian personality correlates with ethnocentrism, close-mindedness, intolerant to ambiguity, prejudice against people that are "different", as well as need for structure or closure. Butler (2000) added that Altemeyer had showed that an authoritarian is not a critical thinker, is a contradictorical thinker, and this shows that the deepest root of the authoritarian personality is more cognitive rather than emotional.

Lately, it is known that RWA is not an immutable trait; rather it is an ideological stance in expressing motivational purposes directed to social adhesion and cohesion as well as collective security and safety (Sibley \& Duckitt, 2010). The motivation was formed from a view that this world is full of threats and danger, and it spawns conformity to existing social order and not the social autonomy. Hing, Bobocel, Zanna, and McBride (2007) found that people with a high level of RWA tends to support unethical decision making. However, it depends on the context; for example, the unethical behavior occurs if the authoritarians are guided by their leader to do so.

The realities in Islamic boarding school were revealed by Faesol, as follows:

The values lived in Indonesia Islamic boarding school ... have unconsciously reincarnated into 'invisible hands' that imprisoned scientific climate of the school ... For santri, questioning and having a different opinion and debating with religious teachers is a form of bad manner ... Obedience is not only dedicated to religious teachers or book authors but also to the family of the religious teachers including their children ... The religious teacher further becomes the only legitimate interpreter of two main sources of Islamic teaching, namely the Qur'an and Hadith (Faesol, 2012, p. 110-112).

If those realities are associated with the study regarding RWA as well as the general religious view in Indonesia, as revealed by Al Qurtuby (2009), "What we are witnessing today is a view of arrogance by religious people (and religious institution) to the phenomenon of vulgar sexuality as unlawful, sinful, immoral and so on"; thus a number of hypotheses can be produced. Based on the literature review described above, this study hypothesized that the higher the level of RWA in individuals, the lower their sexual obsession, sexual permissiveness, and sexual stimulation will be. However, their sexual discordance was hypothesized to be higher.

\section{Methods}

\subsection{Participants and Design}

The design of this study is quantitative, correlational design. Study samples consisted of 271 santris (140 males, 131 females; age of 12-18 years old; $M_{\text {age }}=15.93$ years old; $S D_{\text {age }}=1.69$ years). They were taken using purposive sampling technique from five Islamic boarding schools located in East Java and Yogyakarta, Indonesia. During early adolescence period, transmission of inter-generational ideology (from the authority to the child or adolescent) has taken place, and the adolescent's RWA can be measured (Duriez \& Soenens, 2009). Ideology fills the epistemic needs (or needs for cognition) of individuals, i.e. need for explanation, evaluation, and orientation. The ideology is influenced by relational contexts, such as beliefs of parents as well as peers and reference groups, especially during the development of personal identity (Jost, Federico, \& Napier, 2009). It is not surprising when Erikson (1968) stated that of all imaginable relations, adolescence must make a series of selection regarding 
Khaerina, S. S. \& Abraham, J.

personal, occupational, sexual, and ideological commitment. Similar to Erikson, Marcia (1980, p. 110) stated that the formation of identity does not occur smoothly. At least that formation involves commitment to a sexual orientation, an ideological position or stance, and a vocational direction.

\subsection{Instrument}

The instrument used to measure sexual disorder was Garos Sexual Behavior Inventory (GSBI). GSBI can be used for forensic client and the general population (Davis, 2008; Western Psychological Services, 2012). GSBI consists of 35 items included in four main factors (Garos \& Stock, 1998; Western Psychological Services, 2012), i.e. (1) Sexual discordance reflecting conflict, insecurity, guilt and shame, or uneasiness of individuals to their sexual behavior and sexuality, with sample items, "I feel uncomfortable when a relationship (such as friendship) becomes sexual", "I am afraid that I am not sexually attractive enough", and "I feel uncomfortable about some parts of my body when I am nude"; (2) Sexual obsession reflecting preoccupation towards sex and difficulty in controlling sexual impulses, with sample items, "It feels impossible to stop masturbating", "A life without sex is unnatural", "Once I am aroused, it is difficult not to masturbate or have sex", "It seems like sex is always on my mind", "When I have sexual desires, I must do something to satisfy them", and "Regardless of how busy I am, there is always time for sex"; (3) Sexual permissiveness reflecting "non-conventional", or "non-conservative" sexual values, with sample items, "Extramarital sex is sometimes justified", "I would tolerate my partner having sex with someone else as long as my partner did not leave me", "Sexual play among young children is normal", "Women should not be too sexually aggressive or they may scare a partner away" (unfavorable item; response was reversely scored), "Birth control should be readily available to young people", "Sexual permissiveness is a threat to our society" (unfavorable item), "People should have sex before marriage", and "Women should always wear a bra" (unfavorable item); and (4) Sexual stimulation reflecting comfort toward sexual stimulation and sexual arousal, with sample items, "I look forward to the day when I can stop being sexual" (unfavorable item), "I like not wearing underwear", "I enjoy experiencing my sexual feelings", and "I enjoy being aroused by my sexual thoughts and feelings".

Response options of GSBI are from Strongly Disagree (score of 1) to Strongly Agree (score of 6). Each dimension of GSBI has good reliability (Cronbach's alpha of internal consistency: $\alpha>0.60$ ) and validity (corrected item-total correlations: $r_{i t}>0.25$ ). Complete information along with the number of items which must be eliminated is shown in Table 1.

\section{Table 1}

Reliability and Validity Indexes of GSBI Instrument

\begin{tabular}{lllllll}
\hline No. & Dimension & $\begin{array}{l}\text { Total of } \\
\text { pre-validation } \\
\text { test scale items }\end{array}$ & Cronbach's $\alpha$ & $r_{i t}$ min. & $r_{i t}$ max. & $\begin{array}{l}\text { Total of } \\
\text { post-validation } \\
\text { test scale } \\
\text { items }\end{array}$ \\
\hline 1. & Sexual discordance & 11 & 0.785 & 0.365 & 0.709 & 6 \\
2. & Sexual permissiveness & 11 & 0.725 & 0.318 & 0.703 & 7 \\
3. & Sexual stimulation & 5 & 0.715 & 0.392 & 0.697 & 4 \\
4. & Sexual obsession & 8 & 0.837 & 0.367 & 0.726 & 8 \\
\hline & Total of items & 35 & & & & 25 \\
\hline
\end{tabular}

Instrument used to measure RWA was adapted from RWA scale (Altemeyer, 1996). This instrument consists of three dimensions (Altemeyer, 1990, 1996), namely:

1. Authoritarian submission, i.e. high level of obedience to authorities (individual as well as group) which are considered legitimate or legitimized in society. Sample items are as follow: "Women should have to promise to obey their husbands when they get married", "It is always better to trust the judgment of the proper authorities in government and religion than to listen to the noisy rabble-rousers in our society who are trying to create doubt in people's minds". 
2. Authoritarian aggression, i.e. tendency to do aggression or give sanction toward the deviants, out-group, or other groups which are viewed as unconventional or do not obey the authority. Sample items are as follow: "God's laws about abortion, pornography and marriage must be strictly followed before it is too late, and those who break them must be strongly punished", "The only way our country can get through the crisis ahead is to get back to our traditional values, put some tough leaders in power, and silence the troublemakers spreading bad ideas

3. Conventionalism or conservatism, i.e. high level of willingness to support tradition and social norms which have been approved/legitimized by social authority as well as the belief that other people in society must also be under obligation to obey those norms. Its opponent is "liberalism" or "left wing". Sample items are as follow: "There is no 'One right way' to live life; everybody has to create their own way" (unfavorable item; response was reversely scored), "Homosexuals and feminists should be praised for being brave enough to defy traditional family values" (unfavorable item).

Response options of RWA scale are from Strongly Disagree (score of 1) to Strongly Agree (score of 6). Overall, RWA scale has a good reliability $(\alpha=0.864)$, with a total of pre-validation test scale items of 24 and total of post-validation of 22 , and corrected item-total correlations $\left(r_{i t}\right)$ ranging from 0.275 to 0.560 .

\section{Results}

The descriptions of participants are as follows: Based on participants' ethnicity/race data obtained, it is known that almost all of the participants are Javanese, namely $258(95.2 \%)$ santris. Based on the location data obtained of where participants grow and raise, it is known that almost all of the participants were grown and raised in villages, as many as $188(69.7 \%)$ santris. The rest, namely $83(30.3 \%)$ santris, were grown and raised in the cities. Based on the data obtained of participants' consumption intensity of sexual media, it is known that the majority of participants never consume sexual media, as many as $168(62 \%)$ santris. Based on the data obtained of participants, it is known that $52 \%$ of santris have parents who are religious leader and $48 \%$ of santris whose parents are not religious leader. As many as 92 santris stay at traditional Islamic boarding school, 102 santris stay at modern Islamic boarding school, and 77 santris stay at combination type (traditional mixed with modern) Islamic boarding school. Based on employment data obtained of participants' father, it is known that almost all of the participants have father that are self-employed, as many as $40.2 \%$ of santris. Based on employment data obtained of participants' mother, it is known that the majority of participants mother are housewife, as many as $50.2 \%$ of santris.

Normality data investigation using Kolmogorov-Smirnov test revealed that the data spread was not normally distributed $\left(K-S_{\mathrm{RWA}}=0.091, p<0.05 ; K-S_{\text {sexual discordance }}=0.055, p<0.05 ; K-S_{\text {sexual permisiveness }}=0.155, p<0.05\right.$; $\left.K-S_{\text {sexual stimulation }}=0.124, p<0.05 ; K-S_{\text {sexual obsession }}=0.093, p<0.05\right)$.

Therefore, correlation test on the research data is conducted using non-parametric test, the alternative to Pearson's product moment correlation test, i.e. Spearman's correlation test. It was found that RWA has negative correlation with sexual permissiveness $(\rho=-0.466 ; p<0.01)$, sexual arousal/stimulation $(\rho=-0.322 ; p<0.01)$, and sexual obsession $(\rho=-0.397 ; p<0.01)$. RWA does not correlate with sexual discordance $(\rho=0.304 ; p>$ $0.05)$.

\section{Discussion}

There were three out of four hypotheses that were supported by the empirical data. This study found that there is no correlation between RWA and sexual discordance of santri in Indonesia Islamic boarding school. According to Suschinsky and Lalumière (2012), sexual concordance (as the opposite continuum of sexual discordance) is more influenced by individual's consciousness of their physiological condition. This physiological consciousness among others includes consciousness of heart beat and consciousness of their own breathing or respiration. In men, for example, sexual concordance or discordance is related with penile erection, 
and in women it is related with blood flow to the vagina. They also add an explanation that the psychological aspects which need to be emphasized, resulting in sexual concordance, are psychological aspects related to genital response (sexual organ), especially in male. Sexual and physical arousal in men awakens their sexual motivation. In relation with this study, this means that shame, fear, or sense of comfort regarding one's sexuality is more affected by one's consciousness of their body (bodily awareness) rather than ideology such as RWA.

The absence of the correlation also appears to challenge the results of previous studies by Schmidt (2010) as well as Igartua, Thombs, Burgos, and Montoro (2009) which showed that one's sexual comfort or discomfort is determined by their sexual identity and orientation, whether they are homosexual, heterosexual, or bisexual. Homosexual and bisexual, or its combination, were reported to be more uncomfortable sexually than heterosexual. This implies that RWA should correlate with sexual discordance because RWA for long has been regarded as an attribute of heterosexual. However, further studies are required on whether individuals with a high level of RWA are the same or synonymous with having a heterosexual identity. Reviewing the results of the study by Stones (2006), titled "Antigay prejudice among heterosexual males: Right-wing authoritarianism as a stronger predictor than social-dominance orientation and heterosexual identity", there are indications that RWA is different from heterosexual identity. The evidence, according to Stones' findings, is that RWA has a correlation with prejudice towards homosexual, whereas heterosexual identity does not so. It is also worth investigating on whether RWA and sexual discordance is related indirectly via a mediating variable. As an added explanation, Schmidt (2010) stated that sexual discordance/concordance is also determined by variable levels of alcohol abuse, HIV/AIDS diagnosis, and sexually transmitted diseases.

This study also found that the higher the RWA level, the lower the sexual stimulation will be. Sexual stimulation is a behavior of stimulating the senses whether sexual thoughts or feelings to awaken sexual arousal. Byrne, Fisher, Lamberth, and Mitchell (1974), as well as Griffit (1973) stated that individual with a high level of RWA tend to label their sexual arousal as a negative experience. Byrne et al.'s study (1974) utilized pornography as the sexual arousal media, and found that authoritarians have a more negative response such as disgusted, nauseated, angry, and depressed towards it. Butler (2009) added that sexual arousal for individuals with a high level of RWA are categorized as sexual deviance. Through empirical study, Butler found that individuals with a high level of RWA are more afraid towards situation involving sexual deviance. Based on the results of this study, it is not surprising that RWA negatively correlates with the sexual stimulation dimension of GSBI. When combined with the mediation hypothesis associated with sexual discordance above, the question that arises is: Is it possible that RWA first correlates with sexual stimulation, and furthermore sexual stimulation correlates with sexual discordance? It is clear that RWA does correlate with sexual stimulation in a negative way, as the result of this study. Furthermore, the author tried to correlate sexual stimulation with sexual discordance. It was found that there is a positive correlation between them $(\rho=0.146 ; p<0.05)$. Although the correlation is weak $(\rho<0.25)$, this is a valuable clue for further studies to design a hypothetical pathway as Figure 1.

This study found a negative correlation between RWA and sexual permissiveness. This is close to the Eisenman's research report (1982) which found that individuals whose authoritarianism level have been decreased through experimental manipulation experience an increase in their creativity score, and furthermore increase the level of their sexual behavior, such as premarital intercourse, which was measured one week after experimental manipulation conducted through sexual behavior frequency questionnaire. However, how to explain all of these findings related with one dimension of RWA itself, e.g. authoritarian aggression? Walker, Rowe, and Quinsey (1993) called it as a paradox; because on one side there is a positive correlation between RWA and sexual aggression dimension (compare also: Begany \& Milburn, 2002, regarding positive correlation between RWA and sexual harassment), but on the other side there is a negative correlation between authoritarianism and sexual permissiveness. To explain those: First, there need to be understanding that permissiveness toward sexual aggression is only exhibited to individuals who are deemed worthy or acceptable as target of violence in the authoritarian's perspective, i.e. individuals who deviate and behave unconventional and also are viewed as threatening. In other words, there is an interaction between RWA and the authoritarians' attitude towards individuals they encountered in predicting their sexual aggression (Walker, Rowe, \& Quinsey, 
1993; Begany \& Milburn, 2002). Begany and Milburn also found that there are other variables resulting in sexual aggressions, such as interaction between authoritarianism and individual's belief regarding rape myth and hostile sexism. However, authoritarian conventionalism has a negative attitude towards improper sexual activities (Walker, Rowe, \& Quinsey, 1993), thus lowering sexual permissiveness.

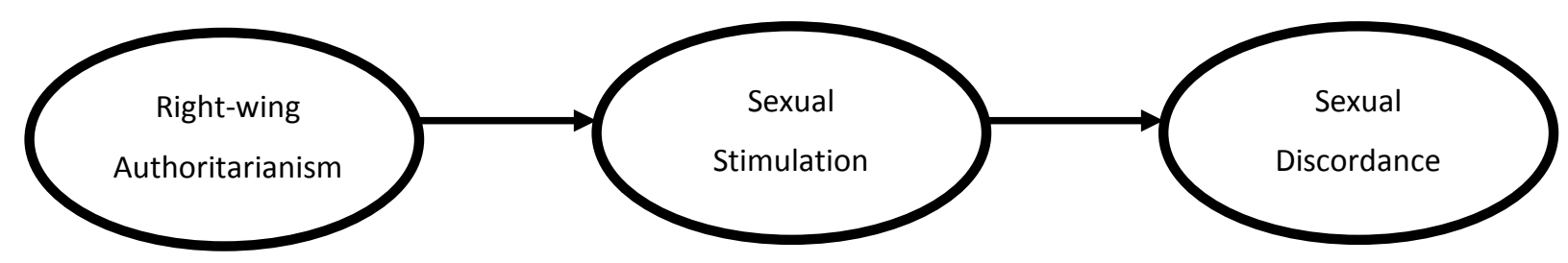

Figure 1. Mediation hypothesis between RWA and sexual discordance (for further testing)

This study found a negative correlation between RWA and sexual obsession. The finding of this study is not in line with Levert's (2005) finding on similar study. Levert found a positive correlation between RWA and internet pornography compulsion. Levert explained that his finding is consistent with the majority of researcher's observation in sexual addiction, where RWA is an important component for the development and maintenance of cybersex addiction. Supporting that proposition, Crouse and Stalker(2007) explained that basically conventionalism of authoritarian can be understood as an effort to control the unknown future and make indeterminate matters into determinate; because of this, there is only one correct way to live for authoritarian. Meanwhile, obsession and compulsion, including in sexual area, is an effort in coping with uncertainties. Obsession involves thought or idea, whereas compulsion involves will and action. Both occur repetitively and ritualistically. However, unlike compulsion, individuals who are addictive are not able to discontinue their adverse behavior.

What is easy to comprehend, based on the explanations above, is the existence of positive correlation between RWA and sexual compulsion in Levert's study (2005). However, there is an assumption told by Levert that is important to emphasize here. He stated, "The right-wing authoritarian compulsive's lack of faith maturity, distorted cognitions, and need to mood-alter produces the impulses to engage habitually in Internet pornography" (p. 17). This statement means that those who experience sexual obsession and addiction are those with a high level of authoritarianism and have immature faith. In other words, authoritarianism and spiritualism should be treated as two distinct constructs. If both of them are different, then according to the author, (1) both can be looked for their correlation; (2) both can interact or not interact. Regarding the first matter, Wink, Dillon, and Prettyman (2007) found that spirituality-seeking negatively correlates with authoritarianism, even though it positively correlates with religiosity. The difference between religiosity and spirituality is as follows (Fowler as cited in Juneman, 2010): religiosity is more a concern about symbol, ritual, doctrine, confession of faith, theology, role, culture, tradition, and religious institution; whereas spirituality or faith is more existential, concerning interpretation or meaning of life and the fundamental orientation of personal life.

It is not surprising that the direction of the correlation between authoritarianism and spiritualism can be contrary to the direction of authoritarianism correlation with religiosity. Regarding the second matter, Levert found an interaction. When individuals have a high level of authoritarianism and low level of spirituality, then sexual obsession/compulsion/addiction occurs. Linked with this study, which actually found a negative correlation between authoritarianism and sexual obsession dimension of Garos, then the question that arises is: Does this mean that the spirituality of the santris participating in this study is high? This matter cannot yet be answered because this study does not measure the spirituality of the santris, however this can become material for further study. 


\section{Conclusion and Recommendation}

This study, to the author's knowledge, is the first which investigated the relationship between RWA and sexual disorders in Islamic boarding school. This study found that RWA does not correlate with sexual discordance; however, RWA has negative correlations with sexual permissiveness, sexual obsession, and sexual stimulation. It means that the higher the RWA level, the lower the sexual permissiveness, sexual obsession, and sexual stimulation will be. The all three are sexuality conditions that seem to be expected from Indonesian people as it is known that Indonesia is a country known for its religious society. Nevertheless, this finding should be interpreted carefully. The author does not practically implies to unnecessarily increase the RWA level of individuals (for example through parenting and education pattern) thus lowering the three sexual dimensions' level.

The implication of this study results is that every stream in the society (either of ethnicity, religions, politics, professions, or others) need to monitor the authoritarianism levels of its members in order to maintain and improve their wellbeing. This is based on the consideration that sexual health and welfare is an integral part of a person's wellbeing (Family Planning Association, 2011). If the authoritarianism levels are low, then based on the research results, most of the sexual disorders will be high. On the other hand, if the authoritarianism levels are high, then most of the sexual disorders will be low. In this case, those with low authoritarianism levels need to be intervened in terms of their sexual life domain (for example, through sexuality education), so that they would not experience many sexual disorders. However, those with high authoritarianism levels need to be intervened in terms of their own authoritarianism state. This is due to that fact that high or extreme authoritarianism levels could lead to depression (Duriez et al., 2012) and other unfortunate consequences as stated below.

Users of this study results are required to carefully consider the fact that RWA has other features that the author did not find desirable, namely the inability to think critically, as well as prejudice and discrimination towards individuals that are considered as different or viewed to be destabilizing the world order; as stated in the Introduction section of this article. In addition, there are evidences which indicate that RWA raises defensive mechanisms (Edger, 2012; Walker, Rowe, \& Quinsey, 1993). Walker, Rowe, and Quinsey (1993), for example, stated that there is a possibility that individuals with authoritarian perspective are less heterosocially skilled and might place themselves less in sexual situations that require mutual consent. However, according to their assessment, individuals with high RWA are not necessarily abstinent sexually; rather they keep searching for sexual contact during certain facets of their life. Edger (2012) showed the existence of defense mechanism with psychoanalytic nuance, namely reaction formation, outlined with sexual scandal cases among religious leaders who should have a high level of RWA. This is not surprising because historically the foundation of authoritarianism theory in the beginning is the classical psychoanalysis of Sigmund Freud. Individuals with a high level of RWA experience an imbalance between the id, ego, and superego; where the superego becomes inflated and experience too much pressure, resulting in anxiety, and forms an exaggerated defensive reaction, such as exaggerated cynicism, excessive hypocrite, and even displacement of sexual behavior (such as secretly performing a "severe sex scandal"). This explains why the mairil phenomenon and the like occur in the Indonesia Islamic boarding school, even though the study result shows an inverse correlation between RWA of the santris and their sexual obsession, permissiveness, and stimulation.

The entire discussions on the result of this study suggest further study by adding mediator and/or moderator variables so a more comprehensive explanation regarding the relationship between correlated variables can be obtained. Generalization of this study results may be limited as a consequence of the use of non-parametric statistical test. 


\section{References}

Adorno, T. W., Frenkel-Brunswik, E., Levinson, D. J., \& Sanford, R. N. (1950). The authoritarian personality. New York: Norton.

Al Qurtuby, S. (2009). Agama, seks, dan moral: Dalam jihad melawan ekstrimis agama, membangkitkan Islam progresif [actual title in Indonesian]. Retrieved June 6, 2014, from http://insistnet.com/index.php?option=com_content\&view=article\&id=7:islam-progresi

Altemeyer, B. (1981). Right-wing authoritarianism. Manitoba, Canada: University Press.

Altemeyer, B. (1990). Altemeyer replies. Canadian Psychology, 31(4), 393-396. http://dx.doi.org/10.1037/h0084416

Altemeyer, B. (1996). The authoritarian spector. Cambridge: Harvard Press.

Asfriyati, \& Sanusi, S. R. (2006). Gambaran karakteristik, keluarga, dan perilaku seksual santri di pesantren purba baru [actual title in Indonesian]. Jurnal Komunikasi Penelitian, 18(1), 1-4.

Begany, J. J., \& Milburn, M. A. (2002). Psychological predictors of sexual harassment: Authoritarianism, hostile sexism, and rape myths. Psychology of Men \& Masculinity, 3(2), 119-126. http://dx.doi.org/10.1037/1524-9220.3.2.119

Botcherby, S., \& Creegan, C. (2009). Moving forward: Putting sexual orientation in the public domain. Retrieved August 22, 2014, from http://www.equalityhumanrights.com/sites/default/files/documents/research/research40_so_moving_for ward.doc

Butler, J. C. (2000). Personality and emotional correlates of right-wing authoritarianism. Social Behavior and Personality, 28(1), 1-14. http://dx.doi.org/10.2224/sbp.2000.28.1.1

Butler, J. C. (2009). Authoritarianism and fear of deviance. North American Journal of Psychology, 11(1), 49-64.

Byrne, D., Fisher, J. D., Lamberth, J., \& Mitchell, H. E. (1974). Evaluations of erotica: Facts or feelings. Journal of Personality and Social Psychology, 29, 111-119. http://dx.doi.org/10.1037/h0035731

Crouse, J., \& Stalker, D. (2007). Do right-wing authoritarian beliefs originate from psychological conflict? Psychoanalytic Psychology, 24(1), 25-44. http://dx.doi.org/10.1037/0736-9735.24.1.25

Davis, J. (2008). Texas Tech sex expert publishes test for sexual problems. Retrieved June 6, 2014, from http://today.ttu.edu/2008/03/texas-tech-sex-expert-publishes-test-for-sexual-problems/

Duriez, B., Klimstra, T. A., Luyckx, K., Beyers, W., \& Soenens, B. (2012). Right-wing authoritarianism: Protective factor against or risk factor for depression. European Journal of Personality, 26, 536-549. http://dx.doi.org/10.1002/per.853

Duriez, B., \& Soenens, B. (2009). The intergenerational transmission of racism: The role of right-wing authoritarianism and social dominance orientation. Journal of Research in Personality, 43, 906-909. http://dx.doi.org/10.1016/j.jrp.2009.05.014

Edger, K. (2012). Evangelicalism, sexual morality, and sexual addiction: Opposing views and continued conflicts. Journal of Religion and Health, 51, 162-178. http://dx.doi.org/10.1007/s10943-010-9338-7

Eisenman, R. (1982). Sexual behavior as related to sex fantasies and experimental manipulation of authoritarianism and creativity. Journal of Personality and Social Psychology, 42(4), 853-860. http://dx.doi.org/10.1037/0022-3514.43.4.853

Erikson, E. (1968). Identity: Youth and crisis. New York: Norton.

Faesol, A. (2012). Kyai, otoritas keilmuan dan perkembangan tradisi keilmuan pesantren [actual title in Indonesian]. Jurnal Salam Universitas Muhammadiyah Malang, 15(1), 109-121.

Faizah, U. (2012). Hubungan penalaran moral dengan sikap terhadap perilaku seks bebas pada siswa MA-SMA santri Pondok Pesantren Darus Sholah Jember. Unpublished bachelor's thesis [actual title in Indonesian], Faculty of Psychology, Universitas Islam Negeri Malang, East Java.

Family Planning Association. (2011). Sexual wellbeing and pleasure. Retrieved August 22, 2014, from http://www.fpa.org.uk/sites/default/files/sexual-wellbeing-policy-statement.pdf

Garos, S. (1997). The Garos Sexual Behavior Index: A measure of addictive sexual behavior. Unpublished doctoral dissertation, Arizona State University, Phoenix, United States. 
Garos, S. (2009). Deviant or different? (Book review: Sexual deviance: Theory, assessment and treatment, 2nd ed., edited by D. Richard Laws \& William T. O’Donohue, Guilford Press, New York, 2008, ISBN: 978-1-59385-605-2). Sex Roles, 60, 754-756.

Garos, S., \& Stock, W. A. (1998). Investigating the discriminant validity and differentiating capability of the Garos Sexual Behavior Index, sexual addiction \& compulsivity. Journal of Treatment \& Prevention, 5(4), 251-267. http://dx.doi.org/10.1007/s11199-008-9525-0

Griffit, W. (1973). Response to erotica and the projection of response to erotica in the opposite sex. Journal of Experimental Research in Personality, 6, 330-338.

Hing, L. S. S., Bobocel, D. R., Zanna, M. P., \& McBride, M. V. (2007). Authoritarian dynamics and unethical decision making: High social dominance orientation leaders and high right-wing authoritarianism followers. Journal of Personality and Social Psychology, 92(1), 67-81. http://dx.doi.org/10.1037/0022-3514.92.1.67

Ibrahim. (2013). Perilaku muyak lating di kalangan santri Pondok Pesantren An-Nuriyah Sumenep Madura [actual title in Indonesian]. Humanis, 4(1), 1-9.

Igartua, K., Thombs, B. D., Burgos, G., \& Montoro, R. (2009). Concordance and discrepancy in sexual identity, attraction, and behavior among adolescents. Journal of Adolescent Health, 45(6), 602-608. http://dx.doi.org/10.1016/j.jadohealth.2009.03.019

Jost, J. T., Federico, C. M., \& Napier, J. L. (2009). Political ideology: Its structure, functions, and elective affinities. Annual Review of Psychology, 60, 307-337. http://dx.doi.org/10.1146/annurev.psych.60.110707.163600

Juneman. (2010). Psychology of fashion: Fenomena perempuan [melepas] jilbab [actual title in Indonesian]. Yogyakarta: Lembaga Kajian Islam dan Sosial.

Levert, N. P. (2005). A comparison of Christian and non-Christian males, authoritarianism, and the relationship to internet pornography addiction/compulsion. Unpublished doctoral dissertation, Division of Pastoral Ministries, New Orleans Baptist Theological Seminary, Lousiana.

Marcia, J. E. (1980). Identity in adolescence. In J. Adelson (Ed.), Handbook of adolescent psychology (pp. 159-187). New York: Wiley \& Sons.

Moskowitz, G. B. (2005). Social cognition: Understanding self and others. New York: Guilford Press.

Muhammad, A. (2008). Kepemimpinan santri dan dilema kekuasaan [actual title in Indonesian]. Retrieved August 22, 2014, from http://www.islamlib.com/?site=1\&aid=1259\&cat=content \&cid=11\&title=kepemimpinan-santri-dan-dile ma-kekuasaan

Nugrahawati, E. N., \& Qodariah, S. (2011). Profil peran teman sebaya, religiusitas dan perilaku seksual pranikah pada mahasiswa [actual title in Indonesian]. Prosiding SNaPP-Sosial Ekonomi, dan Humaniora, Universitas Islam Bandung, West Java, 51-58.

O’Hanlon, M. G. (2006). Pesantren dan dunia pemikiran santri: Problematika metodologi penelitian yang dihadapi orang asing [actual title in Indonesian]. ACICIS Program XXI, 2005-2006, University of Muhammadiyah Malang, East Java. Retrieved June 6, 2014, from http://www.acicis.murdoch.edu.au/hi/field_topics/MOHanlon.pdf

Price, M. E. (2013). Why does morality focus so much on sex? Retrieved August 22, 2014, from http://www.psychologytoday.com/blog/darwin-eternity/201307/why-does-morality-focus-so-much-sex

Rahardjo, T. (2003). Hubungan fantasi seksual dan lama tinggal terhadap kecenderungan perilaku homoseksual pada siswa di lingkungan pergaulan yang homogen di pesantren. Unpublished master's thesis [actual title in Indonesian], University of Gadjah Mada, Yogyakarta, Indonesia.

Rahardjo, T. (2010). Dorongan seksual dan kecenderungan perilaku homoseksual pada santri remaja di pesantren [actual title in Indonesian]. Jurnal Sosial dan Budaya, 3(2), 1-10.

Rohmah, N. (2011). Homoseksualitas dalam dunia pesantren: Studi tentang fenomena lesbianisme di kalangan santriwati di Kabupaten Kudus. Unpublished bachelor's thesis [actual title in Indonesian], State University of Semarang, Center Java, Indonesia.

Saifullah, M. (2008). Adakah kekerasan seksual di pesantren? [actual title in Indonesian]. Retrieved June 6, 
2014, from

http://travel.okezone.com/read/2008/12/24/59/176614/adakah-kekerasan-seksual-di-pesantren

Sari, B. S. (2011). Hubungan konsep diri seksual dengan perilaku seksual pranikah remaja di pondok pesantren putri. Unpublished bachelor's thesis [actual title in Indonesian], Faculty of Psychology, University of Airlangga, Surabaya, East Java.

Schmidt, A. B. (2010). Prevalence, predictors and negative outcomes associated with discordant sexual identity, sexual attraction and sexual behavior. Unpublished doctoral dissertation, Graduate Faculty in Social Welfare, City University of New York.

Setiyowati, A. (2008). Faktor-faktor yang mempengaruhi perilaku seksual remaja santri pondok pesantren di Kelurahan Meteseh, Kecamatan Tembalang, Kota Semarang. Unpublished bachelor's thesis [actual title in Indonesian], Faculty of Medicine, University of Diponegoro, Semarang, Center Java, Indonesia.

Sibley, C. G., \& Duckitt, J. (2010). The personality bases of ideology: A one-year longitudinal study. The Journal of Social Psychology, 150(5), 540-559. http://dx.doi.org/10.1080/00224540903365364

Stones, C. R. (2006). Antigay prejudice among heterosexual males: Right-wing authoritarianism as a stronger predictor than social-dominance orientation and heterosexual identity. Social Behavior and Personality, 34(9), 1137-1150. http://dx.doi.org/10.2224/sbp.2006.34.9.1137

Suschinsky, K. D., \& Lalumière, M. L. (2012). Is sexual concordance related to awareness of physiological states? Archives of Sexual Behavior, 41, 199-208. http://dx.doi.org/10.1007/s10508-012-9931-9

Ulya, I. N. (2010) Hubungan komunikasi interpersonal remaja dengan perilaku seksual di Pondok Pesantren Wahid Hasyim Yogyakarta. Unpublished bachelor's thesis [actual title in Indonesian], Sunan Kalijaga State Islamic University, Yogyakarta, Indonesia.

Walker, W. D., Rowe, R. C., \& Quinsey, V. L. (1993). Authoritarianism and sexual aggression. Journal of Personality and Social Psychology, 65(5), 1036-1045. http://dx.doi.org/10.1037/0022-3514.65.5.1036

Western Psychological Services. (2012). Garos Sexual Behavior Inventory (GSBI). Retrieved June 6, 2014, from http://portal.wpspublish.com/portal/page?_pageid=53,235419\&_dad=portal\&_schema=PORTAL

Wink, P., Dillon, M., \& Prettyman, A. (2007). Religiousness, spiritual seeking, and authoritarianism: Findings from a longitudinal study. Journal for the Scientific Study of Religion, 46(3), 321-335.

http://dx.doi.org/10.1111/j.1468-5906.2007.00361.x 
Khaerina, S. S. \& Abraham, J. 